\title{
Variation in Unit Cell Parameters with Crystallization Temperature in Poly(ether diphenyl ether ketone)
}

\author{
Xiang Ling $\mathbf{J}_{\mathbf{I}}{ }^{\dagger}$ Xue Fei QIU, ${ }^{*}$ Wan Jin Zhang, ${ }^{* *}$ Zhi Shen Mo, \\ Hong Fang ZHANG, and Zhong Wen WU** \\ Polymer Physics Laboratory, Changchun Institute of Applied Chemistry, \\ Chinese Academy of Sciences, Changchun 130022, People's Republic of China \\ * Department of Basic Sciences, Jilin Agricultural University, \\ Changchun 130118, People's Republic of China \\ ** Polymer Laboratory, Department of Chemistry, Jilin University, \\ Changchun 130023, People's Republic of China
}

(Received November 17, 1997)

KEY WORDS Poly(ether diphenyl ether ketone)/Crystallization Temperature / Unit Cell Parameters /

Poly(ether ether ketone) (PEEK), a semicrystalline thermoplastic, is usually a temperature-resistant high performance resin and reinforced matrix. It undergoes the widest conceivable range of processing to produce engineering components and it can be applied in various areas of engineering including aerospace, automobile, and electricity. ${ }^{1}$ Many authors have studied its crystal structure. ${ }^{2-17}$ Each cell has two molecular chains, one crosses through the center, and another occupies four corners and is shared with three other molecular chains. The $c$-axis direction parallels molecular chains which align with zigzag. Two opinions are proposed on the length of $c$-axis, i.e., it occupied a $2 / 3$ repeat unit with about $10 \AA,{ }^{2-7}$ Wakelyn $^{8}$ reported a $c$-axis owning two repeat units with $30 \AA$. A schematic description is shown in Figure la. The average length of three parts $(1,2,3)$ is about $10 \AA$ and the sum is $30 \AA$.

\section{EXPERIMENTAL}

Poly(ether diphenyl ether ketone) (PEDEK) was synthesized with 4,4'-diphenol and 4,4'-difluorobenzophenone, diphenylsulfone as solvent and alkali metal carbonate as catalyst through a nucleophilic substitution route. The glass transition temperature $\left(T_{\mathrm{g}}\right)$ of $171^{\circ} \mathrm{C}$ and melting temperature $\left(T_{\mathrm{m}}\right)$ of $409^{\circ} \mathrm{C}$ were measured by differential scanning calorimeter (DSC). The powered resin, with inherent viscosity $\eta_{\mathrm{iv}}=1.30 \mathrm{dl} \mathrm{g}^{-1}$ measured in $98 \%$ concentrated $\mathrm{H}_{2} \mathrm{SO}_{4}$ at $25^{\circ} \mathrm{C}$, was molded at $440^{\circ} \mathrm{C}$ and a sheet was quenched as quickly as possible into ice/water mixture, this piece of sheet is demonstrated to be amorphous by wide angle X-ray diffraction (WAXD) pattern.

WAXD was measured using a PW1700 diffractometer (Philips Co., Holland) with a nickel-filter and $\mathrm{Cu}-K_{\alpha}$ radiation at a scanning rate of $0.3^{\circ} \mathrm{min}^{-1}$ in a range $5^{\circ} \leq$ $2 \theta \leq 60^{\circ}$.

The film was used in the note.

\footnotetext{
${ }^{\dagger}$ To whom correspondence should be addressed.
}

\section{RESULTS AND DISCUSSION}

Figure $1 \mathrm{~b}$ shows two ether diphenyl ether ketone (EDEK) repeat units. Parts 1 and 2 are longer than part 3 , accept Wakelyn's idea, i.e., the length of $c$-axis includes two repeat units. Figure 2 exhibits the WAXD pattern, for the sample with a greater crystallinity because it was annealed for a long time on a hot press machine. The four main diffraction peaks were located at $18.73^{\circ}$, $19.89^{\circ}, 22.97^{\circ}$, and $28.20^{\circ}$ corresponding to the reflection of $110,113,200$, and 213 . The cell parameter by least square method, was $a=7.74 \pm 0.03 \AA, b=5.98 \pm 0.02 \AA$, $c=37.8 \pm 0.4 \AA$, cell volume is $1750 \pm 13 \AA^{3}$, and crystalline density $1.382 \mathrm{~g} \mathrm{~cm}^{-3}$. The above data are thus

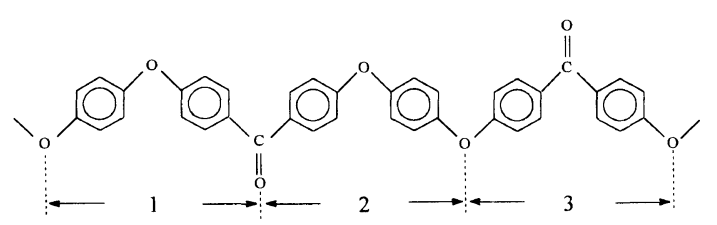

(a)

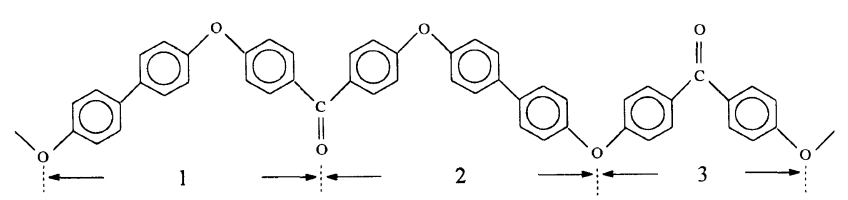

(b)

Figure 1. Two repeat units of PEEK (a) and PEDEK (b).

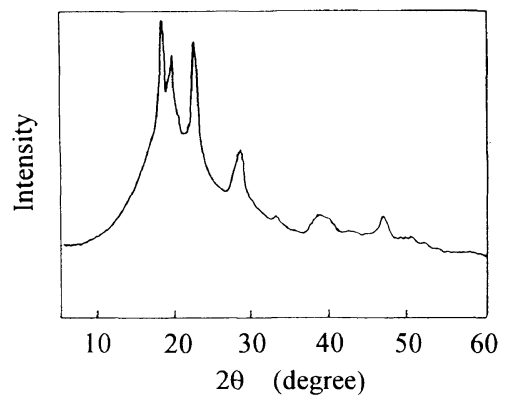

Figure 2. WAXD pattern of PEDEK cooled slowly from the melt to the ambient temperature. 
in agreement with the results reported by Blundell, ${ }^{9}$ i.e., $a=7.72 \AA, b=5.94 \AA, c=37.5 \AA$.

Wakelyn investigated PEEK lattice parameters with annealing temperature from $189^{\circ} \mathrm{C}$ to $323^{\circ} \mathrm{C}$. The dimensions of $a$ - and $b$-axes decreased with annealing tem-

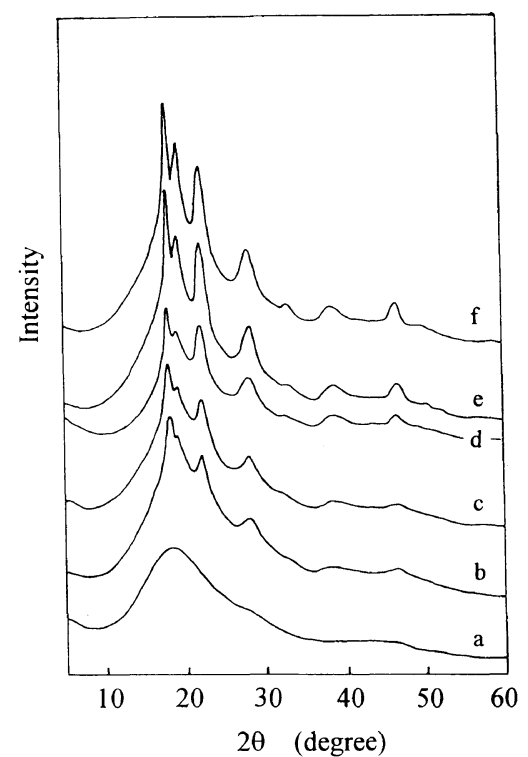

Figure 3. WAXD patterns of PEDEK crystallized at a given temperature for $30 \mathrm{~min}$. a, amorphous; b, $200^{\circ} \mathrm{C} ; \mathrm{c}, 230^{\circ} \mathrm{C} ; \mathrm{d}, 280^{\circ} \mathrm{C}$; e, $350^{\circ} \mathrm{C} ; \mathrm{f}, 390^{\circ} \mathrm{C}$.

perature and the length of $c$-axis show no regularity. Hay $^{10}$ reported the decrease in $a-, b$-, and $c$-axes with crystallization temperature except at $250^{\circ} \mathrm{C}$ possibly due to the maximum crystallization rate appearing at this temperature, and some re-arrangement of atoms within the cell must occur.

The samples ${ }^{8,9}$ were annealed at a temperature for a given time, and measured by X-ray diffractometer at room temperature. Blundell ${ }^{11}$ selected uniaxially drawn sample, which was examined in the transmission mode using copper $K_{\alpha}$ with a Philips vertical goniometer to which was attached a thermostatically controlled hot stage, X-ray can scan at a given temperature. The thermal expansion rate in $a$-axis is about three times greater than in the $b$-axis. The overall cell volume increased linearly with temperature up to $300^{\circ} \mathrm{C}$. Blundell's test belongs to

Table I. The main diffraction peak positions at different crystallization temperatures

\begin{tabular}{lllll}
\hline & \multicolumn{4}{c}{$2 \theta /$ degree } \\
\cline { 2 - 5 }$T_{\mathrm{c}} /{ }^{\circ} \mathrm{C}$ & $(110)$ & $(113)$ & $(200)$ & $(213)$ \\
\hline 200 & 18.35 & 19.55 & 22.44 & 28.35 \\
230 & 18.35 & 19.56 & 22.50 & 28.40 \\
280 & 18.39 & 19.64 & 22.50 & 28.53 \\
350 & 18.58 & 19.78 & 22.70 & 28.71 \\
390 & 18.58 & 19.78 & 22.92 & 28.98 \\
\hline
\end{tabular}
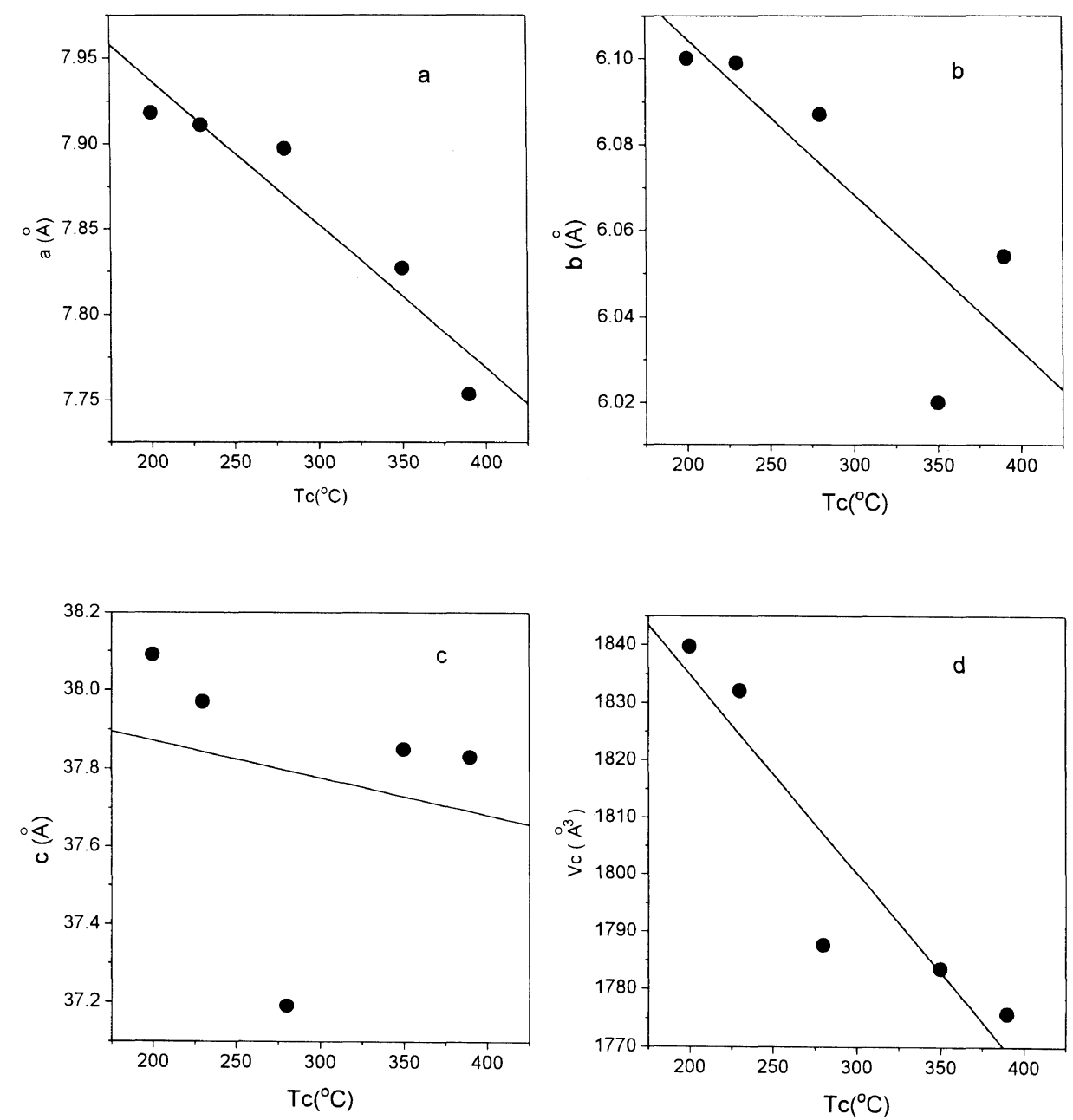

Figure 4. Variation of cell parameters with crystallization temperature. a, $a$-axis; $\mathrm{b}, b$-axis; $\mathrm{c}, c$-axis; $\mathrm{d}$, volume of a cell. 
a dynamic process.

PEDEK films were crystallized at a temperature for 30 min. The WAXD patterns are shown in Figure 3. Diffraction peak positions are listed in Table I. The following equation was used to calculate the cell parameters by least square to fit experimental data.

$$
\frac{1}{d_{h k l}^{2}}=\frac{h^{2}}{a^{2}}+\frac{k^{2}}{b^{2}}+\frac{l^{2}}{c^{2}}
$$

Variation of cell parameters with crystallization temperature is illustrated in Figure 4. As shown in Figure 4 , the length of $a$-axis decreased rapidly, and $b$ - and $c$-axes become small and the overall cell volume shrank with crystallization temperature. This conclusion has been obtained from other poly(aryl ether ketone). ${ }^{7,10}$ The shrinkage rate in $a$-axis is larger than the $b$ and $c$-axes. On increasing crystallization temperature, of the torsional angle of benzyl ring becomes larger, and this gives rise to change in lateral packing of the molecular chain and the torsional angle of phenylene ring and the bridge bond angle of diaryl carbonyl and ether. Steric effects of the adjacent ortho-hydrogen decrease and the bridge bond angles in $\mathrm{C}-\mathrm{CO}-\mathrm{C}$ and $\mathrm{C}-\mathrm{O}-\mathrm{C}$ decrease. Thus the $c$-axis shortens with close packing in $a$ - and $b$-direction. However, the $c$-axis is extraordinarily small at $280^{\circ} \mathrm{C}$ perhaps due to rapid crystallization rate at this temperature. The temperature for the maximum crystallization rate (theoretical value) is about $300^{\circ} \mathrm{C}$. The linear regression analysis gives shrinkage for $a, b$, and $c$-axes and volume of cell.

$$
\begin{aligned}
& a(T)=8.33\left(1-1.01 \times 10^{-4} T\right) \pm 0.03 \AA \\
& b(T)=6.28\left(1-5.74 \times 10^{-5} T\right) \pm 0.02 \AA \\
& c(T)=38.32\left(1-2.51 \times 10^{-5} T\right) \pm 0.4 \AA \\
& V c(T)=1999\left(1-1.73 \times 10^{-4} T\right) \pm 13 \AA^{3}
\end{aligned}
$$

$T$ is Kelvin temperature.

Acknowledgments. Thank for the support of "863" high technology fund of China.

\section{REFERENCES}

1. D. P. Jones, D. C. Leach, and D. R. Moore, Polymer, 26, 1385 (1985)

2. P. C. Dawson and D. J. Blundell, Polymer, 21, 577 (1980).

3. D. R. Rueda, F. Ania, A. Richardson, I. M. Ward, and F. J. Balta Calleja, Polym. Commun., 24, 258 (1983).

4. J. N. Hay, D. J. Kemmish, J. I. Langford, and A. I. M. Rae, Polym. Commun., 25, 175 (1984).

5. J. N. Hay, D. J. Kemmish, J. I. Langford, and A. I. M. Rae, Polym. Commun., 26, 283 (1985).

6. A. V. Fratini, E. M. Cross, R. B. Whitaker, and W. W. Adams, Polymer, 27, 861 (1986).

7. H. J. Zimmermann and K. Könnecke, Polymer, 32, 3162 (1991).

8. N. T. Wakelyn, Polym. Commun., 25, 306 (1984).

9. D. J. Blundell and V. Bayon, Polymer, 34, 1354 (1993).

10. J. N. Hay, J. I. Langford, and S. R. Lloyd, Polymer, 30, 489 (1989).

11. D. J. Blundell and J. D'Mello, Polymer, 32, 304 (1991).

12. D. J. Blundell, Polymer, 33, 3773 (1992).

13. R. J. Abraham and I. S. Haworth, Polymer, 32, 121 (1991).

14. H. M. Colquhoun, C. A. O'Mahoney, and D. J. Williams, Polymer, 34, 218 (1993).

15. D. J. Blundell, J. J. Liggat, and A. Flory, Polymer, 33, 2475 (1992).

16. N. T. Wakelyn, J. Polym. Sci., Part C: Polym. Lett., 25, 25 (1987).

17. D. J. Blundell and A. B. Newton, Polymer, 32, 308 (1991). 